\title{
Constraints Faced by the Paddy Farmers of Shivamogga District
}

\author{
C. Kavyashree*, Basavaraj Beerannavar, B. M. Dharmaraj and B. Dhananjaya \\ Department of Agricultural Extension, College of Agriculture, University of Agricultural and \\ Horticultural Sciences, Shivamogga, India \\ *Corresponding author
}

\section{A B S T R A C T}

\begin{tabular}{|l|}
\hline Ke y w or d s \\
$\begin{array}{l}\text { Paddy, Constraints, } \\
\text { and Suggestions }\end{array}$ \\
\hline Article Info \\
$\begin{array}{l}\text { Accepted: } \\
\text { 07 January } 2021 \\
\text { Available Online: } \\
\text { 10 February 2021 }\end{array}$ \\
\hline
\end{tabular}

Rice is the staple food for two-thirds of the Indian population. India ranks second in the world next to China by producing 155.62 million metric tonnes from an area of 43.20 million ha. It accounts for 20 percent of the total production in the world. The present study throws light on the paddy growers' various constraints and possible suggestions to overcome from these suggestions. A total of 120 respondents constituted the study sample from three talukas of Shivamogga district, having the highest area under paddy cultivation. A clear majority $(98.83 \%)$ of farmers expressed that infestation of pest and disease was the primary constraint followed by low price/less profit margin $(95.00 \%)$, non-availability of agricultural labors $(72.50 \%)$, more drudgery $(68.33 \%)$, lack of information on recent developments in agriculture (62.50\%), unpredictable and irregularity of monsoon (50.00 $\%)$, Etc. Among the suggestions offered, enhancement of minimum support price for paddy at regular intervals $(95.00 \%)$ ranks first, followed by developing disease/pestresistant variety $(92.50 \%)$, and the government should extend support for paddy farming $(86.67 \%)$. The other suggestions include the creation of awareness in farmers on crop insurance schemes $(79.20 \%)$, promotion of mechanization/ custom hiring system (76.67 $\%)$, conducting IPM related training programs (71.67\%), Etc.

\section{Introduction}

Paddy (Oryza sativa L.) is life and prince among cereals. Its major pivotal role in the Indian economy is the staple food for twothird of the population (World Bank 1995). India ranks second globally with production of 155.62 million metric tones from an area of 43.20 million ha. It accounts for 20 percent of the total production in the world. The National Commission on Agriculture has estimated that India's food grain requirement by the end of the century is around 225 million tonnes. The possibility of further area expansion for rice has now reached that limit in most rice-growing countries, including India. In this context, there is an imperative need to improve the production of food grains, especially rice crop being the staple food of south India. The total rice-growing area of Karnataka is 15.13 lakh hectares and total production of about 38.02 lakh tonnes with a productivity of $2644 \mathrm{~kg} / \mathrm{ha}$. In Karnataka, major rice-growing districts are Bellary, Davangere Mysore, Mandya, and Shivamogga. 
Shivamogga district comes under medium productive region with about 1.29 lakh ha, and production of 3.13 lakh tonnes with 2516 $\mathrm{kg} / \mathrm{ha}$ productivity as the district is having intense fertile soil for the cultivation of paddy crop having both command and rainfed area. Shivamogga district being a malnad area traditionally known for paddy cultivation, and people of the district have been cultivating the crop for ages. In recent years, the area under paddy is declining year by year due to various reasons. Therefore, the present study was conducted to identify the constraints faced by paddy farmers and seek their suggestions to overcome them.

Nguyen Cong Thanh et al., (2006) in their study on constraints faced by the farmers in rice production and export, observed that Farmers perceived dependence on the monsoon as the most important constraint (64.00\%); Major Rice diseases and pests such as sheath blight, blast, stem rot diseases and stem borer were perceived as most severe constraints by 80.00 and 78.00 percent of respondents, respectively and lack of proper varieties as perceived by 60.00 percent of respondents.

Maheriya et al., (2015) conducted a study on Constraints experienced, and suggestions offered by farmers in the adoption of recommended paddy production technology reported that lack of knowledge about the recommended dose of fertilizers $(70.83 \%)$, High cost of fertilizers and pesticides (70.83 $\%)$, labor shortage at the time of transplanting and harvesting $(75.00 \%)$, Low market price of paddy $(62.50 \%)$, Poor contacts of extension workers with farmers $(58.33 \%)$ were the major constraints expressed by the farmers.

\section{Materials and Methods}

The study was conducted in three talukas of the Shivamogga district, namely Bhadravathi,
Soraba, and Sagara. From each taluka, four villages were selected based on the highest area under paddy cultivation. Five farm men and five farm women were randomly selected from each village. From 12 villages of three talukas, 60 farm men and 60 farm women were selected. Thus, a total of 120 respondents constituted a sample for the study. The criteria for selecting respondents were the family having both husband and wife involved in agriculture and cultivating paddy crop for three years. The ex-post facto research design was used, and the data was collected through a personal interview method using a structured interview schedule. Frequency and percentage are used to interpret the results.

\section{Results and Discussion}

\section{Constraints expressed by the respondents}

The results presented in Table-1 reveal the constraints expressed by the paddy farmers, among that great majority $(98.83 \%)$ of farmers expressed that infestation of pest and disease was the major constraint. The probable reason for this could be the Shivamogga district being the malnad area continuous rainfall during Kharif season and due to low-temperature incidence of diseases like blast and sheath rot. Incidence of armyworm, stem borer, and planthoppers was also noticed during recent years. Low price for the paddy produce $(95.00 \%)$ was the second major constraint. This was due to paddy procurement from the states like Chhattisgarh and Punjab, where there are a surplus production and inelastic demand from the consumers. The minimum support price announced by the government is around Rs. $1,550 /$ - only, which is low compared to other crops. Non-availability of agricultural labors and more drudgery work were the constraints expressed by 72.50 percent and 68.33 percent, respectively. In the recent past, due to the migration of rural youth and agricultural 
laborers to nearby towns/cities, there is a scarcity of labor of farming operations. Due to high wages for the works in areca garden and fewer drudgery works, laborers prefer to work in areca garden rather than in paddy fields. Seventy-five of the respondents $(62.50$ $\%$ ) expressed lack of information on recent developments in agriculture followed by less contact of extension workers with farmers $(58.33 \%)$ this is due to the wide ratio of extension workers to farmers. Fifty percent of the respondents expressed the problem of unpredictable and irregularity of monsoon. Smaller sized landholding was the constraint expressed by 46.67 percent of farmers. This was due to the result of the fragmentation of landholding in nuclear families. These farmers grow paddy for domestic purposes only rather than for marketing purposes. The scarcity of water for agriculture $(44.17 \%)$ was expressed by farmers of the command area and sorabha taluk due to irregularity of rainfall and the non-availability of water in the command area.

Table.1 Constraints expressed by the respondents $n=120$

\begin{tabular}{|c|c|c|c|c|}
\hline & & & & \multirow{2}{*}{$\begin{array}{c}\mathrm{N}=120 \\
\text { Rank }\end{array}$} \\
\hline SI.No & Constraints & $\begin{array}{c}\text { Frequency } \\
\text { (No.) }\end{array}$ & $\begin{array}{c}\text { Percentage } \\
(\%)\end{array}$ & \\
\hline 1. & Pest and disease problem & 118 & 98.33 & I \\
\hline 2. & Low price/Less profit margin & 114 & 95.00 & II \\
\hline 3. & Non-availability of agricultural labors & 87 & 72.50 & III \\
\hline 4. & More drudgery & 82 & 68.33 & IV \\
\hline 5. & $\begin{array}{l}\text { Lack of information on resent developments } \\
\text { in }\end{array}$ & 75 & 62.50 & $\mathbf{V}$ \\
\hline & Agriculture & & & \\
\hline 6. & $\begin{array}{l}\text { Less contact of extension workers with } \\
\text { farmers }\end{array}$ & 70 & 58.33 & VI \\
\hline 7. & Unpredictable and irregularity of monsoon & 60 & $\mathbf{5 0 . 0 0}$ & VII \\
\hline 8. & Smaller sized landholding & 56 & 46.67 & VIII \\
\hline 9. & The scarcity of water for agriculture & 53 & 44.17 & IX \\
\hline 10. & Weed infestation & 45 & 37.50 & $\mathbf{X}$ \\
\hline
\end{tabular}


Table.2 Suggestions given by the respondents $n=120$

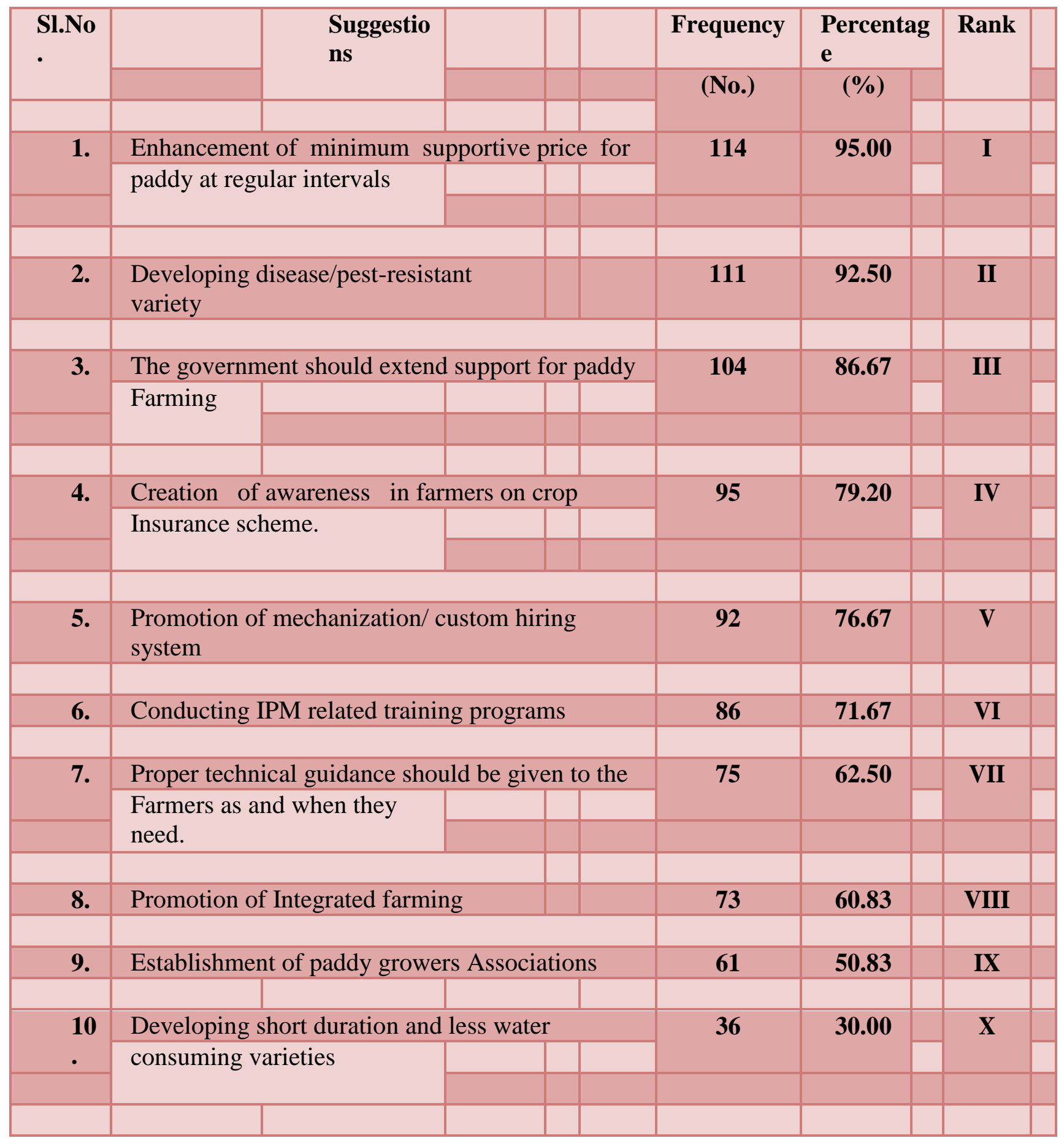


Plate.1 Locale of the study

\section{Karnataka State}

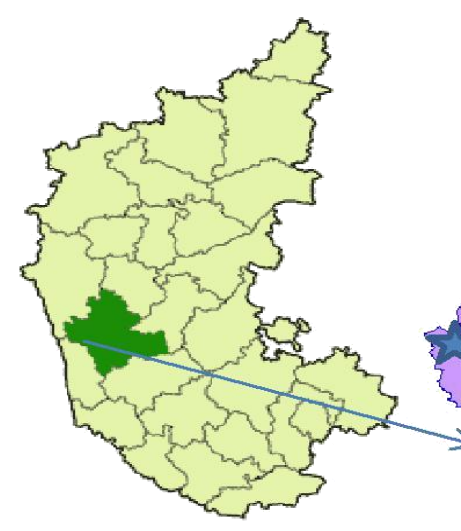

Suggestions expressed by the respondents

Table 2 shows the suggestion given by paddy farmers. The majority $(95.00 \%)$ of farmers suggested that there must be an enhancement of minimum support price for paddy at regular intervals. This suggestion was due to less minimum support price for the paddy given by GOK, i.e., Rs.1550/quintal. Developing disease/pest-resistant variety and conducting IPM related training programs were suggested by 92.50 percent and 71.67 percent, respectively. The farmers of the malnad area had faced a severe reduction in paddy yield due to the incidence of pests and diseases.

About 86.67 percent of farmers suggested that the government should extend support for paddy farming since the area under paddy and the number of farm families cultivating paddy is reducing year by year hence the suggestion. Around eighty percent $(79.20 \%)$ of farmers suggested creating awareness in farmers on crop insurance scheme in case of failure of the crop. Since the farmers are not Aware of the crop insurance schemes of the government, hence some of the respondents suggested this. More than $3 / 4^{\text {th }}$ of farmers (76.67 \%) suggested promoting mechanization/ custom hiring due to the scarcity of laborers and the high cost of

Shivamogga Dist.

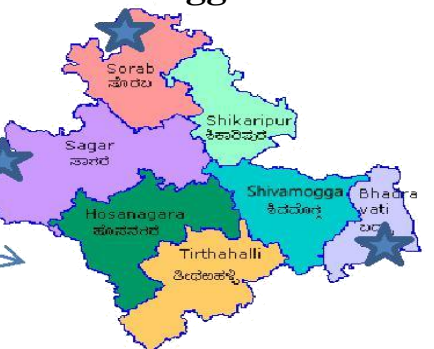

machinery. Promotion of integrated farming was suggested by 60.83 percent of farmers because the income from paddy crop is less, which can be enhanced by practicing paddy based integrated farming system. Establishment of paddy growers associations $(50.83 \%)$ and developing short duration less water consuming varieties $(30.00 \%)$ were the other suggestions offered by the paddy growers.

In conclusion the paddy being the staple crop of the majority of the Indians, it is necessary to retain the area under paddy cultivation. The government should extend additional support for paddy growing the farming community to compensate for less return from paddy cultivation. There is a need to evolve high yielding, disease-resistant, short duration, and less water consuming paddy varieties.

\section{References}

Maheriya, H.N., Patel, R.C. and Patel, J.B., 2014, Constraints faced by farmers in adoption of recommended paddy production Technology, Gujarat J. Extn. Edu., 25 (1): 93-95.

Nguyen cong Thanh and Baldeo, S., 2006, constraints faced by the farmers in rice production and export. Omonrice, 14:97-110. 
World Bank, 1995, Gender Issue in Participation: Social Development Note no. 12. Environmentally and socially sustainable development network of World Bank, Washington, D.C

\section{How to cite this article:}

Kavyashree, C., Basavaraj Beerannavar, B. M. Dharmaraj and Dhananjaya, B. 2021. Constraints Faced by the Paddy Farmers of Shivamogga District. Int.J.Curr.Microbiol.App.Sci. 10(02): 571-576. doi: https://doi.org/10.20546/ijcmas.2021.1002.067. 